\title{
The inhibitory effect of a non-yessotoxin-producing dinoflagellate, Lingulodinium polyedrum (Stein) Dodge, towards Vibrio vulnificus and Staphylococcus aureus
}

Sonia Quijano-Scheggia ${ }^{1}$, Maribel Barajas-Gonzalez ${ }^{1}$, Hong Chang Lim², Chui Pin Leaw ${ }^{2}$, Aramis Olivos-Ortiz ${ }^{1}$, Juan Gaviño-Rodriguez ${ }^{1}$, Juan Blanco Pérez ${ }^{3}$ \& Stephen S. Bates ${ }^{4}$

1. Centro Universitario de Investigaciones Oceanológicas, Universidad de Colima, Carretera Manzanillo-Barra de Navidad Km 19.5, Colonia El Naranjo. C.P 28860, Manzanillo, Colima, Mexico; quijanosonia@gmail.com, maribel_barajas@ucol.mx, aolivos@ucol.mx; gavinho@ucol.mx

2. Bachok Marine Research Station, Institute of Ocean and Earth Sciences, University of Malaya, 16310 Bachok, Kelantan, Malaysia; hclim24@gmail.com, chuipinleaw@gmail.com

3. Centro de Investigacións Mariñas, Pedras de Corón s/n, Apdo. 13, 36620 Vilanova de Arousa, Spain; juan.carlos. blanco.perez@xunta.es

4. Fisheries and Oceans Canada, Gulf Fisheries Centre, P.O. Box 5030, Moncton, New Brunswick E1C 9B6, Canada; stephen.bates@dfo-mpo.gc.ca

Received 03-VI-2015. Corrected 17-XI-2015. Accepted 09-XII-2015.

\begin{abstract}
The increased bacterial resistance to antibiotics has caused global concern, prompting the search for new compounds. Because of their abundance and diversity, marine phytoplankton are an important potential source of such compounds. Research on dinoflagellates has led to the discovery of inhibitors of bacterial growth. The marine dinoflagellate Lingulodinium polyedrum blooms in different regions of the world, including Mexico, and is also known to regulate the growth of other species in coastal waters. Here, we investigated the taxonomy of this dinoflagellate and characterized the ability of its extracts to inhibit the growth of two bacteria of medical importance (Vibrio vulnificus and Staphylococcus aureus). Taxonomic characterization was performed by PCR and gene amplification of ITS, and confirmed that the species isolated off the Pacific coast of Mexico was L. polyedrum. To prove the inhibitory effect of L. polyedrum extracts, cultures were harvested by centrifugation. Pellets from three cellular abundances were extracted with water, methanol, hexane and chloroform. The experiments on $V$. vulnificus showed a high growth inhibition for the four extracts, ranging from 77 to $98 \%$. Surprisingly, the growth inhibition was lower when the extracts originated from a higher L. polyedrum cell abundance, ranging from 0 to $34 \%$. For $S$. aureus, the growth inhibition was also high, but not statistically different for all extracts and cell abundances, ranging from 62 to $99 \%$. This study obtained promising results for future pharmacological applications. Our Mexican strain of $L$. polyedrum did not produce any detectable yessotoxins. Rev. Biol. Trop. 64 (2): 805-816. Epub 2016 June 01.
\end{abstract}

Palabras clave: proliferaciones algales, antibiótico, resistencia bacteriana, Lingulodinium polyedrum, fitoplancton, Staphylococcus aureus, Vibrio vulnificus, yessotoxina.

Since the discovery of antibiotics in the early 1940s, their clinical use has resulted in greatly improved health care. Human deaths from bacterial infections have been reduced and life expectancy has increased. After the emergence of antibiotic resistance in the 1970s, research has been focused principally on modifications to semisynthetic compounds that were already clinically proven (Stach, 2010). Currently, the resistance of pathogenic bacteria to multiple drugs is a global problem, causing increased concern in health care institutions (Klevens et al., 2007; Fischbach \& Walsh, 2009). One possible solution is to discover and introduce new antibacterial medications. Marine eukaryotic microalgae are a potential 
source of these new compounds; they offer a high genetic diversity and constitute an untapped resource of novel natural products. Their ability to withstand environmental stress and outcompete other marine organisms is related to their capacity to produce a vast array of secondary metabolites, which have considerable value in the biotechnology, aquaculture, health and food industries (Anderson, 1996). Likewise, several studies have reported antibacterial activity in the cell lysates or extracts of various microalgal species (Desbois et al., 2009; Blunt et al., 2011; de Jesus Raposo et al., 2013).

Dinoflagellates are a large group of flagellate protists, belonging mostly to marine phytoplankton, some of which are known to form harmful algal blooms that are an important source of marine biotoxins (Tomas, 1997; Gallardo-Rodríguez et al., 2012). Bioactive compounds from dinoflagellates have received increased attention because of their impact on the safety of seafood and their potential uses in biomedical, toxicological and pharmacological research. Despite the many interesting bioactive compounds isolated from dinoflagellates (Konishi et al., 2004; Camacho et al., 2007; Blunt et al., 2011), only a few have led to commercial products. This is partly due to the limited amount of dinoflagellate toxin that can be amassed for detailed clinical evaluation (Gallardo-Rodríguez et al., 2012). Nevertheless, recent patents and patent applications related to dinoflagellate toxins have been published (Selander \& Pavia, 2008; Paul, 2011). One of the few examples of medical uses is the dinoflagellate toxin, gonyautoxin (Garrido et al., 2005). Lingulodinium polyedrum (Stein) Dodge is a dinoflagellate that blooms in coastal waters of Colima, Mexico (Quijano-Scheggia et al., 2013). It is easy to isolate and maintain in culture. Here, we probe its potential as source of antibacterial compounds against two bacteria of medical importance: Vibrio vulnificus and Staphylococcus aureus. Vibrio vulnificus is a Gram-negative, oxidase-positive, facultative anaerobe. In warm coastal waters, it causes vomiting, diarrhea and abdominal pain, when raw or undercooked shellfish, especially oysters, are consumed (Strom \& Paranjpye, 2000; Tortora Funke \& Case, 2007; Horseman \& Surani, 2011). It has become resistant to various antibiotics (Kim et al., 2011; Shaw et al., 2014). Staphylococcus aureus is a Grampositive facultative anaerobe, which is widely distributed and capable of producing a broad range of diseases, from skin infections to life-threatening illnesses. It, also, has become resistant to several antibiotics (Lowy, 2003), resulting, for example, in Methicillin-resistant Staphylococcus aureus (MRSA) infection (Appelbaum, 2007).

The present study was carried out to discover if cell extracts of $L$. polyedrum may contain antibacterial compound(s) that may inhibit the growth of the pathogenic bacteria $V$. vulnificus and S. aureus.

\section{MATERIALS AND METHODS}

Sampling and culturing: Phytoplankton samples were collected with a plastic bottle during a bloom of L. polyedrum in May 2012, off the coast of Manzanillo, Colima, Mexico $\left(19^{\circ} 7^{\prime} 3.00^{\prime \prime} \mathrm{N}-104^{\circ} 22^{\prime} 23.52^{\prime \prime} \mathrm{W}\right)$, and maintained at $4{ }^{\circ} \mathrm{C}$. Single cells were isolated under a Motic AE31 inverted microscope (Ted Pella, Inc., Redding, California, USA) with a glass Pasteur pipette. They were then transferred to tissue culture plates (Assay Plate 96 Well Flat Bottom, Corning, NY, USA) containing $0.4 \mathrm{~mL}$ of L1 medium (Guillard, 1975) at a salinity of 30 , modified by addition of $10^{-8} \mathrm{M} \mathrm{H}_{2} \mathrm{SeO}_{3}$ and by reducing the concentration of $\mathrm{CuSO}_{4}$ to $10^{-8}$ M (Band-Schmidt et al., 2005). After reaching a density of $10^{4}$ cells/L, the non-axenic cultures were transferred successively to 50,250 and 1000 -mL flasks. All cultures were maintained at $21{ }^{\circ} \mathrm{C}$ under cool-white fluorescent tubes (Phillips F96T12/TL865/EW, 60 W, USA) with an irradiance of $90 \mu \mathrm{mol}$ photons $/ \mathrm{m}^{2}$.s and a 12:12 h light:dark photoperiod. Cell abundance was determined at 200-400 x magnification using a Motic AE31 inverted bright-field light microscope, according to Utermöhl (1931) and Throndsen (1995). 
Gene amplification and sequencing: Cells were harvested during the late exponential growth phase by centrifugation at 2 $000 \times \mathrm{g}$ for $10 \mathrm{~min}$, with a MAX RCT centrifuge (REXMED, Kaohsiung, Taiwan). The pellets were frozen at $-20{ }^{\circ} \mathrm{C}$ and the DNA was extracted following Lundholm, Moestrup, Hasle \& Hoef-Emden (2003). The Internal Transcribed Spacer (ITS1-5.8S-ITS2) region of the rDNA was amplified and sequenced using the primers ITS1 and ITS4 (White Bruns, Lee \& Taylor, 1990).
The ITS rDNA sequences were aligned using ClustalW (Thompson, Higgins, \& Gibbson, 1994). The alignment included 593 positions. Separate analyses of ITS2 were also performed as in Koetschan et al. (2010). The ITS analyses were rooted with seven outgroup taxa (Table 1).

Neighbor-Joining (NJ) and MaximumLikelihood (ML) were performed using MEGA 8 (Kumar, Tamura, \& Nei, 2004). Bayesian analyses were performed using MrBayes 3.1.2 (Ronquist \& Huelsenbeck, 2003), using four chains of 1000 generation each. The

TABLE 1

List of the species and strains used in the present study, including Lingulodinium polyedrum from Manzanillo, Mexico (in bold)

\begin{tabular}{|c|c|c|}
\hline Species & Location & GenBank accession \\
\hline L. polyedrum & Italy & AM184208 \\
\hline L. polyedrum & United Kingdom & EU177126 \\
\hline L. polyedrum & United Kingdom & EU177127 \\
\hline L. polyedrum & United Kingdom & EU177128 \\
\hline L. polyedrum & California, USA & EU532480 \\
\hline L. polyedrum & California, USA & EU532481 \\
\hline L. polyedrum & California, USA & EU532482 \\
\hline L. polyedrum & British Columbia, Canada & FJ823575 \\
\hline L. polyedrum & British Columbia, Canada & FJ823576 \\
\hline L. polyedrum & British Columbia, Canada & FJ823577 \\
\hline L. polyedrum & La Paz, Mexico & JQ616824 \\
\hline L. polyedrum & Manzanillo, Mexico & KR185944 \\
\hline Gonyaulax polyedra & Korea & AF377944 \\
\hline Akashiwo sanguinea & Korea & AY831412 \\
\hline Akashiwo sanguinea & Korea & AY831411 \\
\hline Alexandrium peruvianum & Rhode Island, USA & JX113683 \\
\hline Dinophysis caudata & Maryland, USA & EU780642 \\
\hline Dinophysis caudata & France & AY040584 \\
\hline Gymnodinium catenatum & Korea & DQ779989 \\
\hline Gymnodinium catenatum & Korea & DQ779990 \\
\hline Gyrodinium instriatum & Iran & JN020162 \\
\hline Heterocapsa triquetra & Korea & HQ902267 \\
\hline Karenia brevis & British Columbia, Canada & FJ823563 \\
\hline Karenia brevis & British Columbia, Canada & FJ823562 \\
\hline Oxyrrhis marina & United Kingdom & FJ853681 \\
\hline Oxyrrhis marina & United Kingdom & GQ487326 \\
\hline Prorocentrum micans & Maryland, USA & EU780638 \\
\hline Prorocentrum micans & New Brunswick, Canada & EU927533 \\
\hline Scrippsiella trochoidea & China & JQ250798 \\
\hline Scrippsiella trochoidea & Germany & HQ729501 \\
\hline
\end{tabular}


temperature was set to 0.25 . Sample frequency was 500 , and the number of burn-in generations was 5000 .

The secondary structure of ITS2 was predicted using RNAstructure ver. 5.7 (Mathews et al., 2004). Our strain of $L$. polyedrum from Manzanillo (Table 1) was used as a template for homologous modeling of other L. polyedrum strains through ITS2 Database (http:// its2-old.bioapps.biozentrum.uni-wuerzburg.de/ cgi-bin/index.pl?custom) (Schultz et al., 2006; Selig, Wolf, Mülle, Dandekar, \& Schultz, 2008; Koetschan et al., 2010). Helices were recognized by comparing the ITS2 regions of several $L$. polyedrum sequences obtained from the above ITS2 database. The helices were named according to Mai \& Coleman (1997). Secondary structures of $L$. polyedrum ITS2 were illustrated by VARNA (Darty Denise \& Ponty, 2009).

Crude extracts: Exponential-phase $L$. polyedrum cells were harvested by centrifugation for $10 \mathrm{~min}$ each at $2500 \times \mathrm{g}$ and then at $20000 \times \mathrm{g}$, at $4{ }^{\circ} \mathrm{C}$, with the same centrifuge as above. Three cell abundances of $L$. polyedrum were used for each test of antibacterial activity (see below). The pellets were lyophilized using a FreeZone 6 lyophilizer (Labconco, Missouri, USA). Four separate extractions were performed on the pellets by adding $1.5 \mathrm{~mL}$ of water, methanol, hexane or chloroform for $10 \mathrm{~min}$. Silicon pearls were added to each solvent and then cells were disrupted using a Mini-BeadBeater (Biospec, Oklahoma, USA) for $10 \mathrm{~s}$. Each supernatant was then placed in an Eppendorf tube and allowed to evaporate at room temperature. The extracts were stored in the evaporated state at $4{ }^{\circ} \mathrm{C}$ and then resuspended in $500 \mu \mathrm{L}$ of sterile distilled water just prior to use.

Experiments to test for antibacterial activity: To determine if there was antibacterial activity in the compounds extracted from L. polyedrum, two bacteria were used: Vibrio vulnificus (ATCC 27562, Gram-negative) and Staphylococcus aureus (ATCC 29213,
Gram-positive). The former was incubated in tryptone soy broth and the latter in Brain Heart Infusion (BHI) broth, each for $24 \mathrm{~h}$ at 35-37 ${ }^{\circ} \mathrm{C}$. The bacterial abundance in the broth was standardized to 0.05 absorbance units (at 400 $\mathrm{nm}$ ) with a Jenway 6500 spectrophotometer (Staffordshire, UK). One $\mu \mathrm{L}$ of each broth was then diluted into $999 \mu \mathrm{L}$ of Phosphate Buffered Saline (PBS) and labeled as standardized bacterial dilution (SBD).

Inhibition experiments were carried out in triplicate by adding $10 \mu \mathrm{L}$ of SBD to 10,25 and $50 \mu \mathrm{L}$ of each extract and completing to 100 $\mu \mathrm{L}$ with PBS. As a control, $10 \mu \mathrm{L}$ of SBD was added to $90 \mu \mathrm{L}$ of distilled water. Each tube was incubated for $2 \mathrm{~h}$ at $35-36{ }^{\circ} \mathrm{C}$, after which three drops of each solution were placed onto single Petri plates made with tryptone soy agar for $V$. vulnificus and BHI agar for $S$. aureus. As a control, three drops of SBD solution were placed onto another Petri plate. The Petri plates were incubated for $24 \mathrm{~h}$ at $35-37^{\circ} \mathrm{C}$. Cell colonies were counted in the control plates and compared to those numbers in each cell extract and cell abundance treatment, and the percent inhibition for each treatment was then calculated. The control ranged from 15 to 30 Colony Forming Units (CFU). The Student's t-test was used to determine whether the results were statistically significant.

Toxin extraction and analysis: The $L$. polyedrum extracts were examined for the possible presence of yessotoxins (YTXs) and some analogs and derivatives (Table 2), as this dinoflagellate is a known producer of YTXs (Paz et al., 2008). YTXs were extracted from $50 \mathrm{~mL}$ of late-exponential phase L. polyedrum culture, centrifuged for $10 \mathrm{~min}$ each at $2500 \times \mathrm{g}$ and then at $20000 \times \mathrm{g}$, as above. The pellets were extracted with $10 \mathrm{~mL}$ of methanol and then frozen at $-20{ }^{\circ} \mathrm{C}$ prior to being sent to the Centro de Investigación Médica Aplicada (CIMA; Galicia, Spain) for further processing, as follows. The extract was concentrated in a Thermo SpeedVac rotary evaporator and filtered through a Macherey-Nagel 0.22- $\mu \mathrm{m}$ PES syringe filter. A $10-\mu \mathrm{L}$ aliquot was then injected 
TABLE 2

Main mass spectrometry parameters used in the screening and quantification of yessotoxin (YTX) and its derivatives; all were below the limit of detection

\begin{tabular}{lc}
\multicolumn{1}{c}{ Toxin } & Transition \\
41-ketoYTX & $538.4>396.4$ \\
41-ketoYTX & $538.4>467.4$ \\
TrinorYTX & $550.4>396.4$ \\
TrinorYTX & $550.4>467.4$ \\
Trinor-Homo-YTX & $557.4>403.4$ \\
Trinor-Homo-YTX & $557.4>474.4$ \\
44-oxotrinorYTX & $558.4>404.4$ \\
44-oxotrinorYTX & $558.4>475.4$ \\
44,55-diOH YTX & $565.4>396.4$ \\
41a-homo-44oxotrinorYTX & $565.4>411.4$ \\
44,55-diOH YTX & $565.4>467.4$ \\
41a-homo-44oxotrinorYTX & $565.4>482.4$ \\
YTX & $570.4>396.4$ \\
YTX & $570.4>467.4$ \\
Homo-YTX & $577.4>403.4$ \\
Homo-YTX & $577.4>474.4$ \\
45-OH-YTX & $578.4>396.4$ \\
45-OH-YTX & $578.4>467.4$ \\
45-OH-Homo-YTX & $585.4>403.4$ \\
45-OH-Homo-YTX & $585.4>474.4$ \\
COOH-YTX & $586.4>396.4$ \\
COOH-YTX & $586.4>467.4$ \\
COOH-Homo-YTX & $593.4>403.4$ \\
COOH-Homo-YTX & $593.4>474.4$ \\
COOH-45-OH-YTX & $594.4>396.4$ \\
44,55-diOH-41ahomoYTX & $594.4>403.4$ \\
COOH-45-OH-YTX & $594.4>467.4$ \\
44,55-diOH-41ahomoYTX & $594.4>474.4$ \\
32-O-monoglycosyl-YTX & $636.4>462.4$ \\
32-O-monoglycosyl-YTX & $636.4>533.4$ \\
32-O-diglycosyl-YTX & $702.4>528.4$ \\
32-O-diglycosyl-YTX & $702.4>599.4$ \\
\hline
\end{tabular}

into a LC-MS/MS system composed of a Thermo TSQ Quantum Access Max coupled to an Accela UHPLC system through an HESI-II electrospray interface. The method of Regueiro Martín-Morales, Álvarez \& Blanco (2011) was used, but modified by the use of a $50-\mathrm{mm}$ Gemini NX C18 $3 \mu \mathrm{m}, 2.1 \times 50 \mathrm{~mm}$ column (Phenomenex), and a different elution gradient, as detailed below. The chromatographic phases were $6.7 \mathrm{mM}$ ammonium hydroxide (phase
A) and acetonitrile in $6.7 \mathrm{mM}$ ammonium hydroxide $(9: 1, \mathrm{v}: \mathrm{v})$ (phase B). For the on-line solid-phase extraction (SPE), a Security Guard with a Gemini NX C18 $4 \times 2 \mathrm{~mm}$ cartridge (Phenomenex), and a mixture of phases $\mathrm{A}$ and B (90:10, v/v) as loading phase, were used.

The chromatographic conditions started at $90 \%$ phase A, held until min 1.50 , after which the flow through the SPE column was diverted to the chromatographic column. The percentage of this phase was then reduced to $20 \%, 15 \%$ and $5 \%$ at $\min 3.85,4.00$ and 4.75 , respectively, before being held at $5 \%$ for two additional min. Finally, the conditions were reverted to the initial proportion in order to equilibrate the column for the next injection. The mass spectrometer conditions were as follows: ionization mode: negative spray; voltage: $3000 \mathrm{~V}$; sheet gas: 40 (nominal); auxiliary gas 10 (nominal); vaporizer temp: $105^{\circ} \mathrm{C}$; capillary temp: $360{ }^{\circ} \mathrm{C}$; collision cell gas pressure: 1.5 Torr; collision energy: 30 . The transitions used to identify YTXs are given in Table 2. The limit of detection was $0.13 \mathrm{ng} / \mathrm{mL}$ of extract.

\section{RESULTS}

Morphology: The clonal culture of Lingulodinium polyedrum from Manzanillo was morphologically similar to the original description (Kofoid, 1911). Cells showed a polyedral shape, ranging from 35.6-47.9 $\mu \mathrm{m}$ in length and 30.9-38.4 $\mu \mathrm{m}$ in width $(\mathrm{n}=21)$. Antapical spines and an apical horn were absent. The theca is thick, well defined and areolate, with pores in the depressions. Plate formula: Po, 3', 3a, 6", 6c, 7s, 6" ' and 2"' (Fig. 1).

Phylogenetic inference: The phylogenetic analysis using ITS nucleotide sequences yielded similar tree topologies by NJ, ML and BI. Aligned sequences produced a total of 593 characters (including gaps), of which 489 characters were constant, and 218 variable characters were parsimony informative. Our strain of L. polyedrum from Manzanillo clustered with other strains from different regions of the world in a moderate to strongly supported clade, 


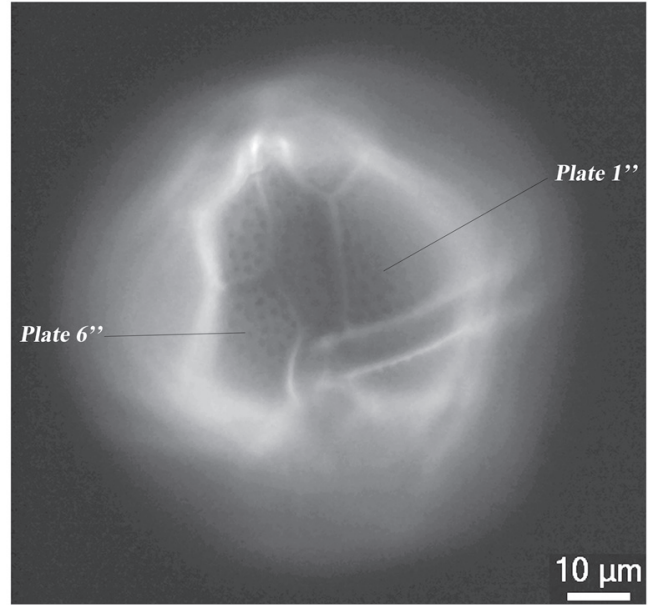

Fig. 1. Ventral views of Lingulodinium polyedrum from Manzanillo. Light microscopy stained with calcofluor white. giving bootstraps values of $99 \%, 64 \%$ and 96 $\%$, for NJ, ML and BI, respectively (Fig. 2).

In general, the ITS2 transcript of L. polyedrum showed four universal helices. The secondary structure of ITS2 of L. polyedrum from Manzanillo showed some genetic divergence with strains from America, Europe and Asia, giving eight Single Nucleotide Polymorphisms (SNPs), four Hemi-Compensatory Base Change (HCBCs) and one deletion (Fig. 3).

Antibacterial activity: The experiment on $V$. vulnificus, using an aqueous extract from $L$. polyedrum with an abundance of $2 \times 10^{6}$ and $5 \times 10^{6} \mathrm{~L}$. polyedrum cells, showed a growth inhibition of $96.4 \%$ and $93.6 \%$, respectively (Fig. 4). For extracts in the other solvents, the

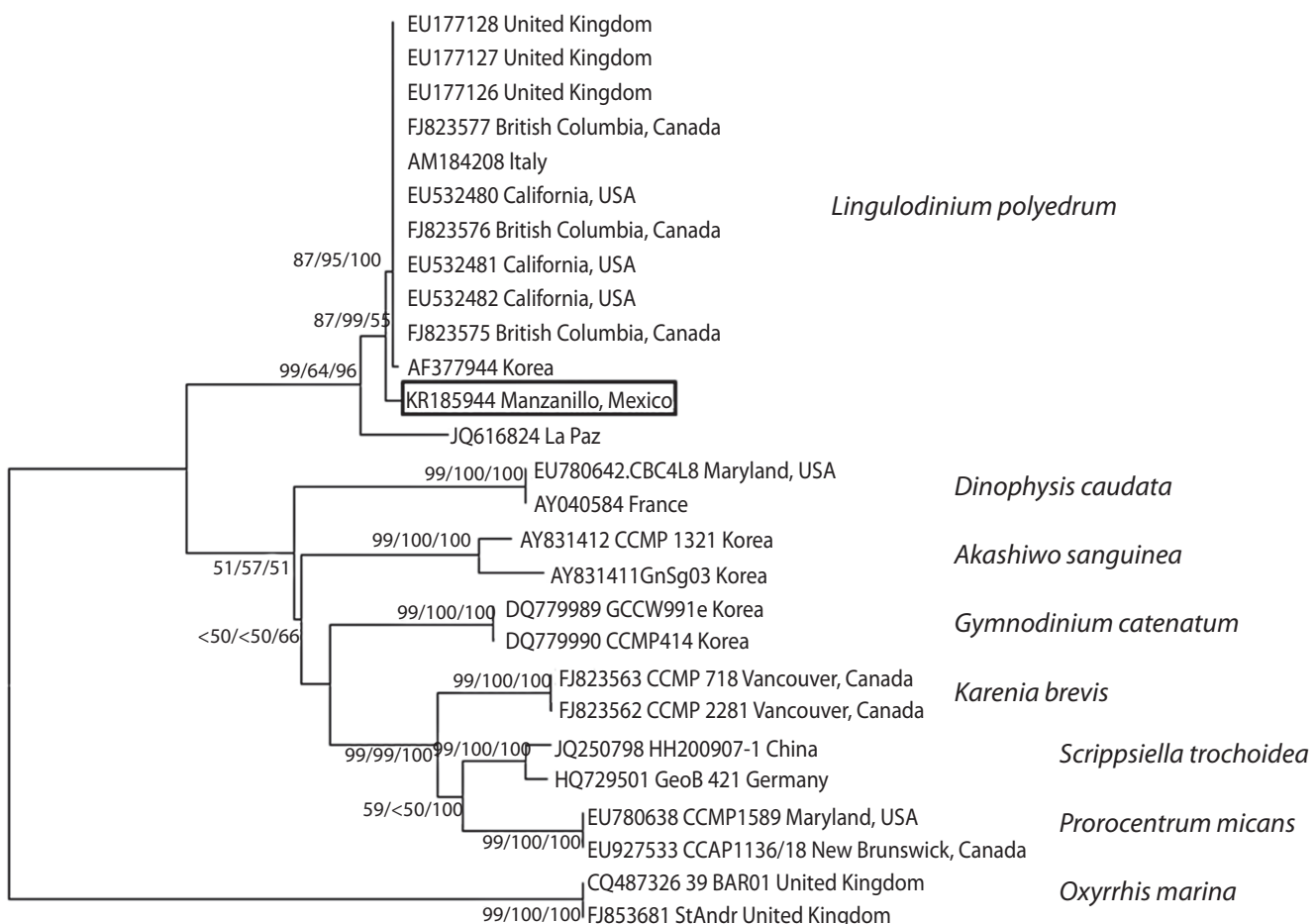

0.1

Neighbor-Joining/Maximum-Likelihood/Bayesian

Fig. 2. Neighbor-joining (NJ) phylogenetic tree of Lingulodinium polyedrum based on ITS1, 5.8S, and ITS2 sequences. Bootstrap values from NJ, maximum likelihood (ML) and Bayesian are shown. Only bootstrap values $>50 \%$ are indicated. Sequence in box indicates strain obtained for the present study (from Manzanillo, Mexico); sequences of the other strains were obtained from GenBank. 


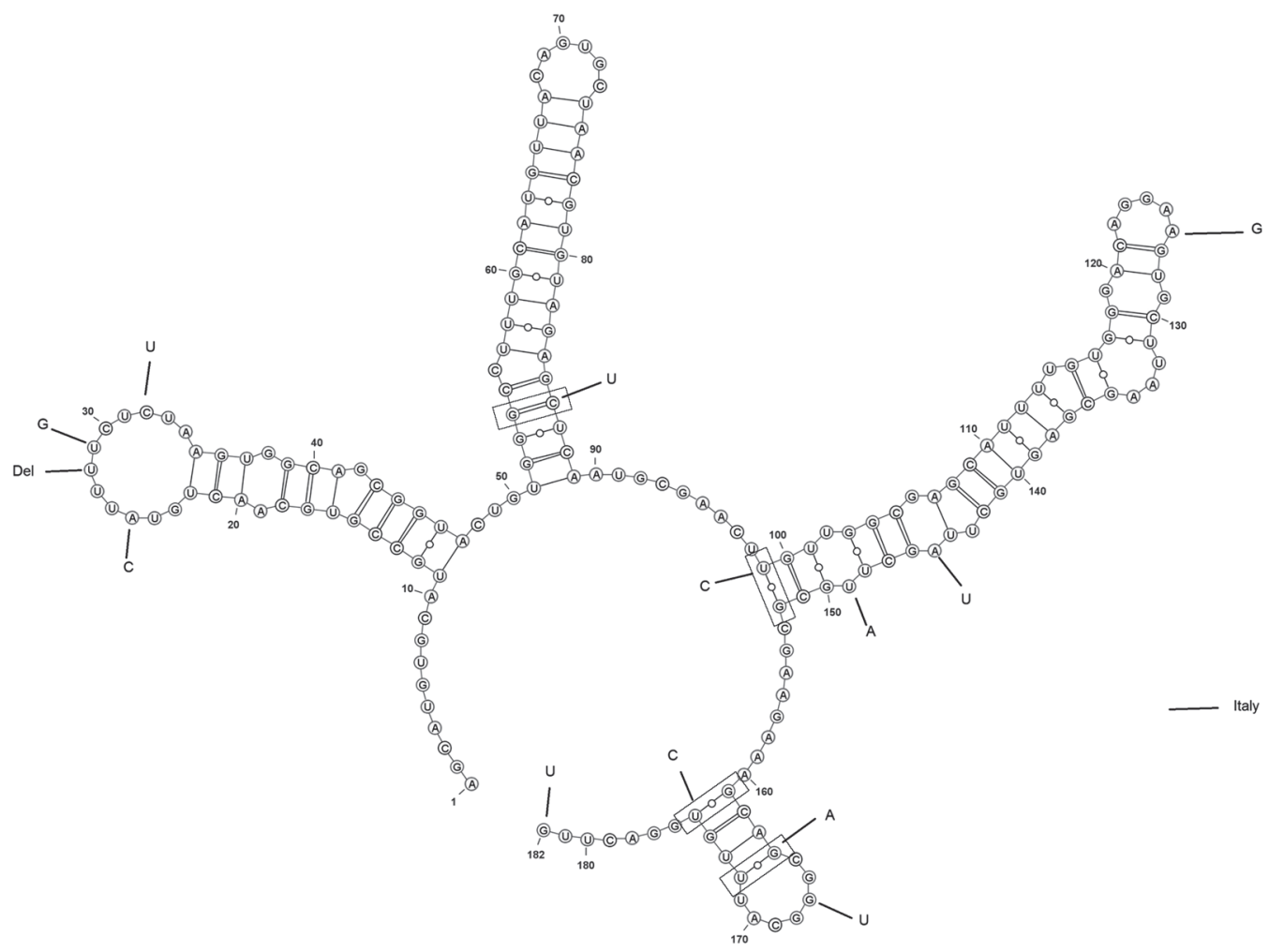

Fig. 3. Secondary structures of ITS2 from Lingulodinium polyedrum from Manzanillo, Mexico. Rectangles indicate hemicompensatory base changes (HCBCs).

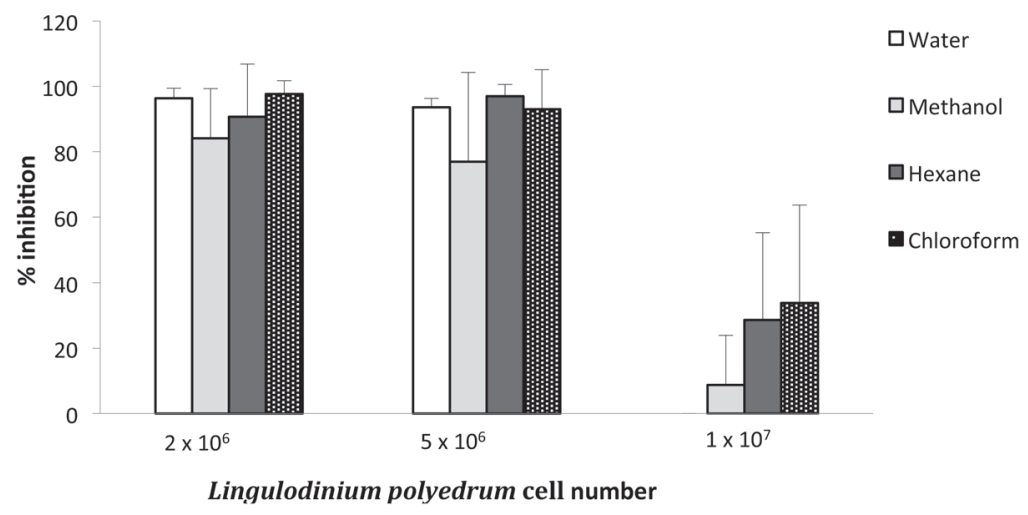

Fig. 4. Percent growth inhibition of Vibrio vulnificus with four extracts and three cell abundances of Lingulodinium polyedrum.

inhibitions were: $84.1 \%$ and $77.0 \%$ (methanol); $90.7 \%$ and $97.0 \%$ (hexane); and $97.7 \%$ and $93.0 \%$ (chloroform), for the two cell abundances, respectively. Using a higher abundance of $1 \times 10^{7}$ cells, the inhibition was lower: 8.8 $\%$ (methanol); $28.6 \%$ (hexane); $33.8 \%$ (chloroform); no inhibition was observed for the aqueous extract (Fig. 4). 
The growth inhibition of $S$. aureus was maximal for abundances of $6.48 \times 10^{4}$ and $1.26 \times 10^{5} \mathrm{~L}$. polyedrum cells for each extract, as follows: $97.6 \%$ and $90.8 \%$ (aqueous); 95.4 $\%$ and $98.2 \%$ (methanol); $98.1 \%$ and $99 \%$ (hexane), for the two cell abundances, respectively (Fig. 5). For the chloroform extract, the inhibition was $97.5 \%$ for a cell abundance of $6.48 \times 10^{4}$, and $98.8 \%$ for $1.26 \times 10^{5}$ cells. The growth inhibition for a cell abundance of $3.24 \times$ $10^{5}$ was lower, ranging from $62.1 \%$ (aqueous) to $69.9 \%$ (hexane) (Fig. 5).

There were significant differences in the growth inhibition of $V$. vulnificus between the different extracts in each group with the $2 \times$ $10^{6}$ and $1 \times 10^{7}$ cell abundances (Table 3 ). With the $2 \times 10^{6}$ and $5 \times 10^{6}$ cell abundances, the difference was significant only for the aqueous

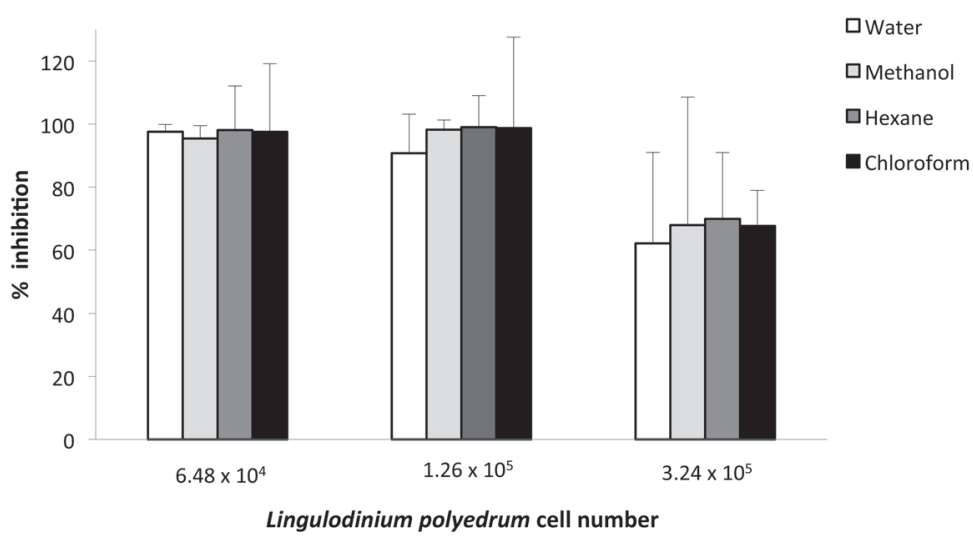

Fig. 5. Percent growth inhibition of Staphylococcus aureus with four extracts and three cell abundances of Lingulodinium polyedrum.

TABLE 3

Student's t-test analysis of the growth inhibition of Vibrio vulnificus, with three cell abundances and four extraction solvents

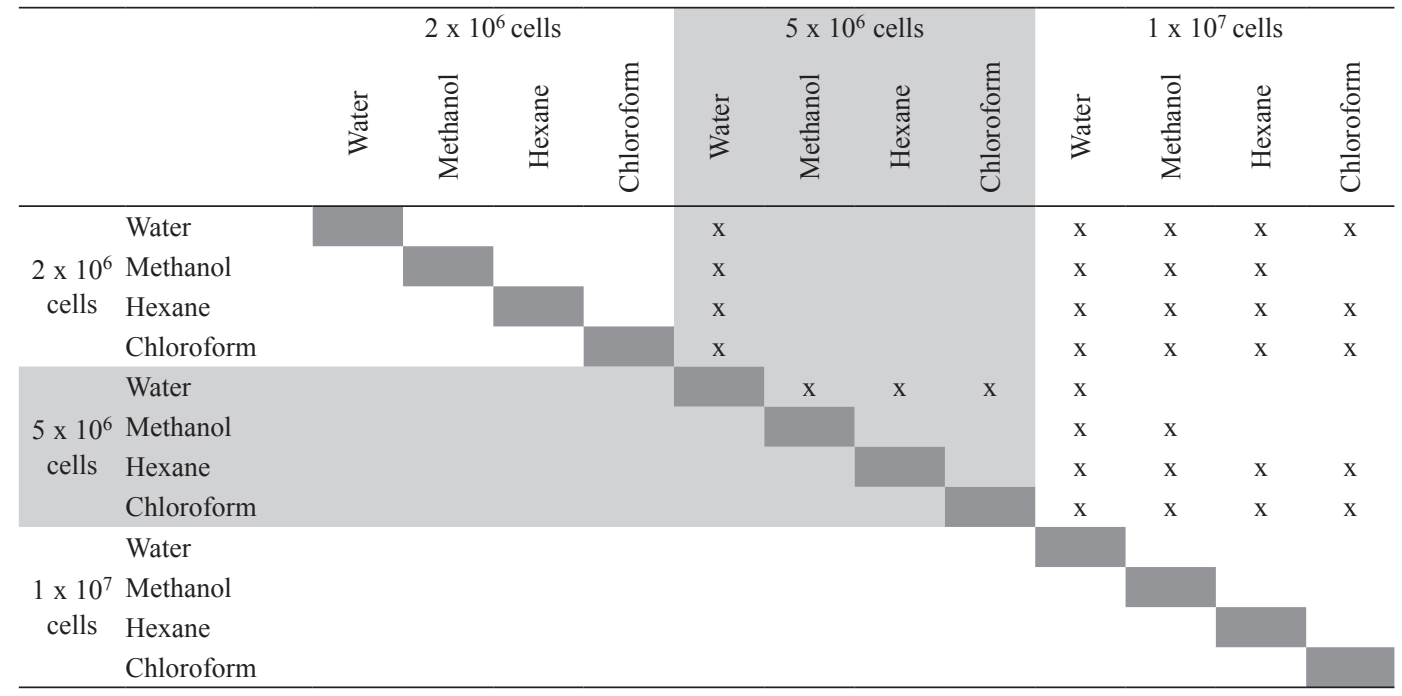

$\mathrm{x}=$ significantly different $(\mathrm{p}<0.05)$. 
extract. For the cells abundances of $1 \times 10^{7}$ and $5 \times 10^{6}$, there were significant differences for most combinations of the different extracts, with the exceptions of the following combinations: water-methanol, hexane-chloroform, and methanol-hexane-chloroform. Results for the experiments with $S$. aureus did not show any significant differences in growth inhibition, for any of the four extracts and three cell concentrations.

Toxin analysis: No YTXs, nor analogs or derivatives, were detected in the L. polyedrum isolates from Manzanillo.

\section{DISCUSSION}

Marine microorganisms remain an abundant source of novel and biologically active metabolites, with 273 new compounds reported up to 2009 (Blunt et al., 2011). Thus, dinoflagellates can also provide numerous and potentially useful bioactive products, although relatively few have been investigated because of a limited supply from nature (GallardoRodríguez et al., 2012).

Our study shows that the strain isolated from Manzanillo, off the Pacific coast of Mexico, belongs to Lingulodinium polyedrum. This species has been described in Mexican Pacific waters (Morquecho \& Lechuga-Devéze, 2004; Peña-Manjarrez, Gaxiola-Castro, \& HelenesEscamilla, 2009; Ruiz-de la Torre, Ochoa, \& Almeda-Jauregui, 2013) as well as worldwide, including upwelling systems (Smayda \& Trainer, 2010). The species identity was confirmed by morphological as well as phylogenetic characterizations. The analysis of the secondary structure of ITS2 showed eight SNPs, four HCBCs and one deletion. Our L. polyedrum strain from Manzanillo did not produce any detectable YTXs or analogues. Other non-toxic strains of L. polyedrum from Norway, Spain and California (USA) have also been reported (Armstrong \& Kudela, 2006). In contrast, toxic strains have been reported from Italy, the United Kingdom, Ireland, Galicia and Andalucía (Spain) (Paz, Riobó, Fernández, Fraga, \&
Franco, 2004; Paz et al., 2008) and California (USA) (Armstrong \& Kudela, 2006).

We confirmed that this non-axenic $L$. polyedrum strain inhibits the growth of $V$. vulnificus and $S$. aureus. The inhibition of $V$. vulnificus growth by extracts in the four solvents was high, with no statistical differences between the L. polyedrum cell abundances of $2 \times 10^{6}$ and $5 \times 10^{6}$, except for the aqueous extract. In contrast, the inhibition was lower when higher cell abundance $\left(1 \times 10^{7}\right)$ was used, and no inhibition was observed for the aqueous extract. We hypothesize that the bioactive compounds trigger the growth inhibition at low concentrations because the compounds can penetrate the cell wall. At higher concentrations, however, they may saturate the receptors on the cell wall, thus not penetrating the cell and allowing bacterial growth. The production of inhibitory compounds may also be higher at low cell abundances. For example, Pérez, Band, Ortíz \& Sobrino. (2014) found that less toxic compounds were generated at higher cell concentrations of Chattonella spp. (Raphidophyceae).

Our results showed that the growth of $S$. aureus is also inhibited by extracts from the four solvents and three cell abundances of L. polyedrum, with no statistically significant differences found among these treatments. Likewise, methanolic extracts from the diatom Chaetoceros muelleri showed effective inhibition of $S$. aureus growth (del Pilar Sánchez, Licea \& Bernáldez 2010). The antibacterial activity from this diatom species has been associated with several fatty acids, which induced lysis in bacterial protoplasts by disrupting the cell membrane. These compounds can penetrate the meshwork of peptidoglycan polymers in the cell wall and reach the bacterial membrane, which leads to the disintegration of Enterobacteriaceae such as E. coli (Shanmugapriya \& Ramanathan, 2011).

These results showed that L. polyedrum contains useful secondary metabolites against $V$. vulnificus and $S$. aureus, and that it could be a source of biologically active compounds with potential application in the pharmaceutical industry. Although many compounds isolated 
from dinoflagellates have shown bioactivities of interest (Camacho et al., 2007; Blunt et al., 2011), only a few have led to commercial products (Gallardo-Rodríguez et al., 2012).

The morphological and molecular characterization of the isolate from Manzanillo, on the Mexican west coast, confirmed it as L. polyedrum. Cell extracts from this dinoflagellate showed a high percentage of growth inhibition against both a Gram-negative ( $V$. vulnificus) and a Gram-positive ( $S$. aureus) pathogenic bacterium. This is the first phase in the quest to obtain antimicrobial agents with possible pharmaceutical uses from L. polyedrum. It is now necessary to identify and evaluate the antibacterial activity of individual compounds, a step that is underway.

\section{ACKNOWLEDGMENTS}

We thank the University of Colima and Terminal KMS de GNL, S. de R.L. de C.V. for the funding provided for this research, Maria Rivera-Vilarelle for her onsite effort and invaluable lab work, and the Centro de Investigación en Alimentación y Desarrollo (Mazatlán, Sinaloa, Mexico) for providing the Vibrio vulnificus strain.

\section{RESUMEN}

El aumento de la resistencia bacteriana a los antibióticos ha causado preocupación a nivel mundial, por lo que se ha promovido la búsqueda de nuevos compuestos. Debido a su abundancia y diversidad, el fitoplancton marino constituye una importante fuente potencial de tales compuestos. La investigación sobre dinoflagelados ha llevado al descubrimiento de inhibidores de crecimiento bacteriano. El dinoflagelado marino Lingulodinium polyedrum causa proliferaciones algales en diferentes regiones del mundo, incluyendo México, y también se sabe que regula el crecimiento de otras especies en las aguas costeras. En este trabajo, se investiga la taxonomía de este dinoflagelado y se caracteriza la capacidad de sus extractos para inhibir el crecimiento de dos bacterias de importancia médica (Vibrio vulnificus y Staphylococcus aureus) en placas de cultivo de agar. La caracterización taxonómica se realizó por PCR y amplificación del gen de ITS, y se confirmó que la especie aislada en la costa del Pacífico de México fue L. polyedrum. Para demostrar el efecto inhibidor de los extractos de L. polyedrum, los cultivos se cosecharon por centrifugación. Los pellets de tres abundancias celulares se extrajeron con agua, metanol, hexano y cloroformo. Los experimentos en $V$. vulnificus mostraron una inhibición alta del crecimiento para los cuatro extractos, variando entre 77 y $98 \%$. Sorprendentemente, la inhibición del crecimiento fue menor cuando los extractos se originaron a partir de una mayor abundancia de células $L$. polyedrum, varía de 0 a $34 \%$. Para $S$. aureus, la inhibición del crecimiento también fue alta, pero no estadísticamente diferente para todos los extractos y abundancias de células, con un rango de 62 hasta $99 \%$. Esto resultados son prometedores para futuras aplicaciones farmacológicas. La cepa mexicana de L. polyedrum no produjo yesotoxinas detectables.

Palabras clave: proliferación de algas, antibioticos, resistaencia bacteriana, Lingulodinium polyedrum, fitoplancton, Staphylococcus aureus, Vibrio vulnificus, yesotoxinas.

\section{REFERENCES}

Anderson, R. A. (1996). Algae. In J. C. Hunter-Cevera, \& A. Belt (Eds.), Maintaining cultures for biotechnology and industry (pp. 29-64). San Diego: Academic Press.

Appelbaum, P. C. (2007). Microbiology of antibiotic resistance in Staphylococcus aureus. Clinical Infectious Diseases, 45(3), 165-170.

Armstrong, M., \& Kudela, R. (2006). Evaluation of California isolates of Lingulodinium polyedrum for the production of yessotoxin. African Journal of Marine Science, 28(5), 399-401.

Band-Schmidt, C. J., Bustillos-Guzmán, J., Gárate-Lizárraga, I., Lechuga-Devéze, C. H., Reinhardt, K., \& Luckas, B. (2005). Paralytic shellfish toxin profile in strains of the dinoflagellate Gymnodinium catenatum Graham and the scallop Argopecten ventricosus G.B. Sowerby II from Bahía Concepción, Gulf of California, México. Harmful Algae, 4(1), 21-31.

Blunt, J. W., Copp, B. R., Munro, M. H. G., Northcote, P. T., \& Prinsep, M. R. (2011). Marine natural products. Natural Product Reports, 28(2), 196-268.

Camacho, F. G., Rodríguez, J. G., Mirón, A. S., García, M. C., Belarbi, E., Chisti, Y., \& Grima, E. M. (2007). Biotechnological significance of toxic marine dinoflagellates. Biotechnology Advances, 25(2), 176-194.

Darty, K., Denise, A., \& Ponty, Y. (2009). VARNA: Interactive drawing and editing of the RNA secondary structure. Bioinformatics, 25(15), 1974-1975.

de Jesus Raposo, M. F., de Morais, R. M. S. C., \& de Morais, A. M. M. B. (2013). Health applications of bioactive compounds from marine microalgae. Life Sciences, 93(15), 479-486. 
del Pilar Sánchez-Saavedra, M., Licea-Navarro, A., \& Bernáldez-Sarabia, J. (2010). Evaluation of the antibacterial activity of different species of phytoplankton. Revista de Biología Marina y Oceanografia, 45(3), 531-536.

Desbois, A. P., Mearns-Spragg, A., \& Smith, V. J. (2009). A fatty acid from the diatom Phaeodactylum tricornutum is antibacterial against diverse bacteria including multi-resistant Staphylococcus aureus (MRSA). Marine Biotechnology, 11(1), 45-52.

Fischbach, M. A., \& Walsh, C. T. (2009). Antibiotics for emerging pathogens. Science, 325 (5944), 1089-1093.

Gallardo-Rodríguez, J., Sánchez-Mirón, A., García-Camacho, F., López-Rosales, L., Chisti, Y., \& Molina-Grima, E. (2012). Bioactives from microalgal dinoflagellates. Biotechnology Advances, 30(6), 1673-1684.

Garrido, R., Lagos, N., Lattes, K., Abedrapo, M., Bocic, G., Cuneo, A., Chiong, H., Jensen, C., Azolas, R., \& Henriquez, A. (2005). Gonyautoxin: new treatment for healing acute and chronic anal fissures. Diseases of the Colon \& Rectum, 48, 335-343.

Guillard, R. R. L. (1975). Culture of phytoplankton for feeding marine invertebrates In W. L. Smith, \& M. $\mathrm{H}$. Chanley (Eds.), Culture of marine invertebrate animals (pp. 29-60). New York: Plenum Publ. Corp.

Horseman, M. A., \& Surani, S. (2011). A comprehensive review of Vibrio vulnificus: an important cause of severe sepsis and skin and soft-tissue infection. International Journal of Infectious Diseases, 15(3), 157-166.

Kim, J. H., Choresca, C. H. Jr., Shin, S. P., Han, J. E., Jun, J. W., \& Park, S. C. (2011). Occurrence and antibiotic resistance of Vibrio vulnificus in seafood and environmental waters in Korea. Journal of Food Safety, 31(4), 518-524.

Klevens, R. M., Morrison, M. A., Nadle, J., Petit, S., Gershman, K., Ray, S., Harrison, L. H., Lynfield, R., Dumyati, G., \& Townes, J. M. (2007). Invasive methicillin-resistant Staphylococcus aureus infections in the United States. Journal of the American Medical Association, 298(15), 1763-1771.

Koetschan, C., Förster, F., Keller, A., Schleicher, T., Ruderisch, B., Schwarz, R., Müller, T., Wolf, M., \& Schultz, J. (2010). The ITS2 Database III-sequences and structures for phylogeny. Nucleic Acids Research, 38(1), D275-D279.

Kofoid, C. A. (1911). Dinoflagellata of the San Diego region. IV. The genus Gonyaulax, with notes on its skeletal morphology and a discussion of its generic and specific characters. University of California Publications in Zoology, 8(4-6), 187-286.
Konishi, M., Yang, X., Li, B., Fairchild, C. R., \& Shimizu, Y. (2004). Highly cytotoxic metabolites from the culture supernatant of the temperate dinoflagellate Protoceratium cf. reticulatum. Journal of Natural Products, 67(8), 1309-1313.

Kumar, S., Tamura, K., \& Nei, M. (2004). MEGA3: integrated software for molecular evolutionary genetics analysis and sequence alignment. Briefings in Bioinformatics, 5(2), 150-163.

Lowy, F. D. (2003). Antimicrobial resistance: the example of Staphylococcus aureus. Journal of Clinical Investigation, 111(9), 1265-1273.

Lundholm, N., Moestrup, Ø., Hasle, G. R., \& Hoef-Emden, K. (2003). A study of the Pseudo-nitzschia pseudodelicatissima/cuspidata complex (Bacillariophyceae): What is P. pseudodelicatissima? Journal of Phycology, 39, 797-813.

Mai, J. C., \& Coleman, A. W. (1997). The internal transcriber spacer 2 exhibits a common secondary structure in green algae and flowering plants. Journal of Molecular Evolution, 44(3), 258-271.

Mathews, D. H., Disney, M. D., Childs, J. L., Schroeder, S. J., Zuker, M., \& Turner, D. H. (2004). Incorporating chemical modification constraints into a dynamic programming algorithm for prediction of RNA secondary structure. Proceedings of the National Academy of Sciences of the United States America, 101(19), 7287-7292.

Morquecho, L., \& Lechuga-Devéze, C. H. (2004). Seasonal occurrence of planktonic dinoflagellates and cyst production in relationship to environmental variables in subtropical Bahía Concepción, Gulf of California. Botanica Marina, 47, 313-322.

Paul, J. H. (2011). Amplifying the target nucleotide sequence of the polyketide synthetase gene to produce an amplified polynucleotide; detecting the presence of the amplified polynucleotide by contacting the amplified polynucleotide with a labeled molecular beacon; for determining the virulence of red tide blooms. Google Patents.

Paz, B., Riobó, P., Fernández, M. L., Fraga, S., \& Franco, J. M. (2004). Production and release of yessotoxins by the dinoflagellates Protoceratium reticulatum and Lingulodinium polyedrum in culture. Toxicon, 44(3), 251-258

Paz, B., Daranas, A. H., Norte, M., Riobó, P., Franco, J. M., \& Fernández, J. J. (2008). Yessotoxins, a group of marine polyether toxins: an overview. Marine Drugs, 6(2), 73-102.

Peña-Manjarrez, J. L., Gaxiola-Castro, G., \& HelenesEscamilla, J. (2009). Environmental factors influencing the variability of Lingulodinium polyedrum and Scrippsiella trochoidea (Dinophyceae) cyst production. Ciencias Marinas, 35(1), 1-14. 
Pérez-Morales, A., Band-Schmidt, C. J., Ortíz-Galindo, J. L., \& Sobrino-Figueroa, A. S. (2014). Mortality in the initial ontogeny of Paralabrax maculatofasciatus (Actinopterygii, Perciformes, Serranidae) caused by Chattonella spp. (Raphidophyceae). Hydrobiologia, 722(1), 247-261.

Regueiro, J., Martín-Morales, E., Álvarez, G., \& Blanco, J. (2011). Sensitive determination of domoic acid in shellfish by on-line coupling of weak anion exchange solid-phase extraction and liquid chromatographydiode array detection-tandem mass spectrometry. Food Chemistry, 129(2), 672-678.

Quijano-Scheggia, S., Olivos-Ortiz, A., Rivera-Vilarelle, M., Gaviño-Rodríguez, J., Álvarez, C., \& SosaAvalos, R. (2013). Cuatro años de monitoreo de fitoplancton en las Bahías de Manzanillo y Santiago. Segundo congreso Somefan. Universidad de Colima, Mazanillo, Colima.

Ronquist, F., \& Huelsenbeck, J. P. (2003). MrBayes 3: Bayesian phylogenetic inference under mixed models. Bioinformatics, 19(12), 1572-1574.

Ruiz-de la Torre, M. C., Maske, H., Ochoa, J., \& AlmedaJauregui, C. O. (2013). Maintenance of coastal surface blooms by surface temperature stratification and wind drift. PLoS One, 8(4), e58958.

Schultz, J., Müller, T., Achtziger, M., Seibel, P. N., Dandekar, T., \& Wolf, M. (2006). The internal transcribed spacer 2 database - a web server for (not only) low level phylogenetic analyses. Nucleic Acids Research, 34, W704-W707.

Selander, E., \& Pavia, H. (2008). Method to enhance production of paralytic shellfish toxins from dinoflagellate cultures. Google Patents.

Selig, C., Wolf, M., Müller, T., Dandekar, T., \& Schultz, J. (2008). The ITS2 Database II: homology modelling RNA structure for molecular systematics. Nucleic Acids Research, 36(1), D377-D380.

Shanmugapriya, R., \& Ramanathan, T. (2011). Screening for antimicrobial activity of crude extracts of Skeletonema costatum. Journal of Applied Pharmaceutical Science, 1(7), 154-157.
Shaw, K. S., Goldstein, R. E. R., He, X., Jacobs, J. M., Crump, B. C., \& Sapkota, A. R. (2014). Antimicrobial susceptibility of Vibrio vulnificus and Vibrio parahaemolyticus recovered from recreational and commercial areas of Chesapeake Bay and Maryland coastal bays. PLoS One, 9(2), e89616.

Smayda, T. J., \& Trainer, V. L. (2010). Dinoflagellate blooms in upwelling systems: seeding, variability, and contrasts with diatom bloom behavior. Progress in Oceanography, 85(1-2), 92-107.

Stach, J. (2010). Antimicrobials: treasures from the oceans. Microbiology Today, 37(2), 104-109.

Strom, M. S., \& Paranjpye, R. N. (2000). Epidemiology and pathogenesis of Vibrio vulnificus. Microbes and Infection, 2(2), 177-188.

Thompson, J. D., Higgins, D. G., \& Gibbson, T. J. (1994). Clustal W: improving the sensitivity of progressive multiple sequence alignment through sequence weighting, position-specific gap penalties and weight matrix choice. Nucleic Acids Research, 22(22), 4673-4680.

Throndsen, J. (1995). Estimating cell numbers. In G. M. Hallegraeff, D. M. Anderson, \& A. D. Cembella (Eds.), Manual on harmful marine microalgae. IOC Manual and Guides (pp. 63-80). Paris: UNESCO.

Tomas, C. R. (1997). Identifying marine phytoplankton. San Diego: Academic Press.

Tortora, G. J., Funke, B. R., \& Case C. L. (2007). Introducción a la Microbiología. Buenos Aires. Médica Panamericana.

Utermöhl, H. (1931). Neue Wege in der quantitativen Erfassung des Planktons. Verhandlungen des Internationalen Verein Limnologie, 5, 567-95.

White, T. J., Bruns, T., Lee, S., \& Taylor, J. (1990). Amplification and direct sequencing of fungal ribosomal RNA genes for phylogenetics. In M. A. Innis, D. H. Gelfand, J. J. Sninsky, \& T. J. White (Eds.), PCR protocols: a guide to methods and applications (pp. 315-322). New York: Academic Press. 